\title{
COMBINATION OF HEDYOTIS CORYMBOSA L. AND TINOSPORA CRISPA ETHANOLIC EXTRACT INCREASE CISPLATIN CYTOTOXICITY ON T47D BREAST CANCER CELLS
}

\author{
ROLLANDO ROLLANDO*
}

Program of Pharmacy, Faculty of Science and Technology, Ma Chung University, Malang, East Java, Indonesia. Email: ro.llando@machung.ac.id Received: 03 March 2018, Revised and Accepted: 02 April 2018

\begin{abstract}
Objective: Ursolic acid was a compound found in Hedyotis corymbosa L., (HCoL) while berberine found in Tinospora crispa (TCa) which are proven to have cytotoxic effect to cancer cells. This research aims to review the effect of cisplatin, ethanolic extract of HCoL and TCa to the sensitivity increase on breast cancer cells, which will be confirmed through apoptosis induction and cell cycle modulation.
\end{abstract}

Methods: The cytotoxic effect was tested using 3-(4,5-dimethylthiazol-2-il)-2,5-diphenyltetrazolium bromide assay on T47D cell using the IC ${ }_{50}$ parameter. The combination was tested by determining their combination index (CI) and cell viability. The combination effect of apoptosis induction and cell cycle modulation was observed using flow cytometry method.

Results: The cytotoxic test result of the combination shows CI value of below 1 at the concentration of HCoL ethanolic extract as much as $1 \mu \mathrm{g} / \mathrm{mL}$, TCa ethanolic extract as much as $6 \mu \mathrm{g} / \mathrm{mL}$, and cisplatin as much as 2,5 $\mu \mathrm{M}$. The combination of HCoL ethanolic extract, TCa ethanolic extract, and cisplatin results in phase $\mathrm{S}$ cell accumulation (29.98\%) on breast cancer cell T47D and was able to induce apoptosis.

Conclusion: The result proves that ethanolic extract of $\mathrm{HCoL}$ and TCa can be developed as a cochemotherapeutic agent with cisplatin to increase the effectivity of breast cancer treatment.

Keywords: Cisplatin, Cytotoxicity, Hedyotis corymbosa L., Tinospora crispa.

(C) 2018 The Authors. Published by Innovare Academic Sciences Pvt Ltd. This is an open access article under the CC BY license (http://creativecommons. org/licenses/by/4. 0/) DOI: http://dx.doi.org/10.22159/ajpcr.2018.v11i7.25607

\section{INTRODUCTION}

Breast cancer was the fifth major causes of total cancer deaths after lung cancer, liver cancer, stomach cancer, and colorectal cancer, but it was the main cause of cancer deaths among women in the world. There were estimated 555.000 women deaths due to breast cancer in 2012 [1,2]. Chemotherapy was a strategy for treating breast cancer after surgery [3]. Chemotherapeutic agents usually show low selectivity properties due to antiproliferative properties against both cancer and normal cells [4]. Besides, chemotherapeutic agents exhibit some negative reaction such as narrow therapeutic index, induce multidrug resistance through several molecular changes [5], and harmful side effects on the cardiovascular system [6]. More selective chemotherapeutic agents development has been done by the production of trastuzumab for HER2 positive breast cancer treatment [7] and everolimus for HER2 negative breast cancer treatment [8]. However, breast cancer therapy using conventional chemotherapeutic agent still widely used due to economical consideration.

Cisplatin was chemotherapeutic agent used in breast cancer therapy as monotherapy or in a combination [9]. Cisplatin induces side effects such as neurotoxicity, nephrotoxicity, and bone marrow suppression [10]. Besides that, usage of cisplatin as a chemotherapeutic agent has an incidence of drug resistance. The drug resistance associated with cisplatin was occurred through changes in: Cellular uptake, drug efflux, inhibition of apoptosis, and regulation on DNA repair. Side effects and resistance due to cisplatin administration can be occurred when high dose of cisplatin was given to reach more effective treatment [11]. Therefore, researches were needed to discover a more effective and selective breast cancer treatment method.

Hedyotis corymbosa L. (HCoL) and Tinospora crispa (TCa) provide high potency to be developed as novel breast cancer chemopreventive agents. HCoL contains ursolic acid that known to have anticancer activities with the mechanism antiproliferative action and antiangiogenesis. Angiogenesis was physiological process in which new blood vessels from pre-existing vessels and was regulated by pro- and anti-angiogenic factors. Angiogenesis was highly needed by tumor cells to spread to another organ or metastatic [12]. Ursolic acid was able to inhibit the regulation of pro-inflammatory cytokines expression through the inhibition of NF- $\kappa B$ activation and antitumor [13]. In the other hand, TCa contains diterpenoid compounds that exhibit cytotoxic activities in human prostate cancer [14].

Administration of chemotherapeutic agents in a combination provides a synergistic effect, increase sensitivity of cancer cells and further reduce dose of each chemotherapeutic agent to be used [15]. Based on the previous researches, the extracts obtained from HCoL to TCa are potential to be combined with cisplatin as a chemotherapeutic agent for breast cancer treatment. The combination between the extract of HCoL and TCa with cisplatin is expected to be able to reduce cisplatin dose and thus will be able to alleviate the side effects and breast cancer cell resistance caused by cisplatin administration. In this research, it was found that combination of HCoL and TCa extracts with cisplatin showed cytotoxic activity to T47D cells through the cell cycle modulation and apoptotic induction.

\section{METHODS}

\section{Materials}

Materials used in this research are HCoL and TCa powder obtained from UPT Materi Materia Medica Batu, Malang. Dimethyl sulfoxide (wako chemical USA), Cisplatin (wako chemical USA), DMEM (Gibco, Invitrogen USA), Fetal Bovine Serum (Gibco, Invitrogen USA), $1.5 \%$ penicillin-streptomycin (v/v) (Gibco, Invitrogen USA), $0.5 \%$ Fungizone (v/v) (Gibco, Invitrogen USA). Tissue culture dish (TCD) (IWAKI), Trypsin-ethylenediaminetetraacetic acid (EDTA) (Gibco, Invitrogen Canada), reagent used was 3-(4,5-dimethylthiazol-2-il)- 
2,5-diphenyltetrazolium bromide (MTT) (Sigma-Aldrich, USA), sodium dodecyl sulfate (Merck-Schuchardt, Germany), and propidium iodide (PI) solution in phosphate-buffered saline (PBS) which contains $1 \mathrm{mg} /$ $\mathrm{ml}$ (minimum 95\% (high-performance liquid chromatography), SigmaAldrich Co., St Louise, MO, 63178, triton X-100 for GC, (E. Merck, 64271, Darmstadt, Germany), and annexin V-FLOUS Apoptosis Detection Kit (Roche, USA).

\section{Instruments}

The instruments used in this research were autoclave (Hirayama HV 25 020585175, Hirayama Manufacturing Co., Japan), liquid nitrogen, Labconco purifier Class II biosafety cabinet (Delta Series, Labconco Corporation, Missouri, USA), $\mathrm{CO}_{2}$ incubator (Heraeus), inverted microscope (Nikon, Eclipse, TE 2000-U), hemocytometer (Neubauer improved $0.100 \mathrm{~mm}$ Tiefe Depth Profondeur $0.0025 \mathrm{~mm} 2$, Germany), cell counter, micropipette (Pipetman ${ }^{\circledR}$ neo Gilson, France), digital camera (Sony), centrifuge (Sigma 203, B.Braun Biotech International), digital scale (Mettler Toledo, AG204 Delta Rang ${ }^{\circledR}$ ), stirrer (Nuova, Thermolyne), mixer (Maxi Mix II, Thermolyne type 37600 mixer, lowa, USA), oven (Memmert), and ELISA reader (Bio-Rad microplate reader Benchmark serial no. 11565, Japan), FACTScalibur flow cytometer.

\section{Extraction}

The flower of HCoL and the stem of TCa were cleaned and washed with running water, then dried under $50^{\circ} \mathrm{C}$ for 4 days. The flower of HCoL and the stem of TCa were grinded to form a powder. Maceration method was used to extract using $96 \%$ ethanol as solvent. About $250 \mathrm{~g}$ of the powder were weighed and diluted in $1 \mathrm{~L}$ of ethanol and macerated for 1 day. On the next day, extract filtering was done using flannel cloth. The extract obtained was then evaporated to separate ethanol and the extract of both plants. The precipitate was then re-macerated. After the extract thickened, it was deemed to be suitable for further test.

\section{Identification chemical compounds}

$1 \mathrm{mg}$ of HCoL and TCa extracts were weighed and diluted in $1 \mathrm{~mL}$ of ethanol. The diluted extract is then spotted on a plate. The mobile phase used was chloroform:ethanol 9:1 (v/v). Then, a chamber to place the mobile phase was prepared and thin layer chromatography (TLC) test was performed. The TLC plate was inserted and set aside until the mobile phase reached the top. After the mobile phase reached the top, the plate was removed from the chamber and was sprayed with cerium sulfate and Dragendorff reagents. The plate is then dried briefly in the oven and the spot formed is used to calculate the hRf value.

\section{Preparation of test solution}

The solution stock of HCoL and TCa ethanolic extracts were diluted using culture medium to the concentration of $1,10,25,50,100,75$, and $200 \mu \mathrm{g} /$ $\mathrm{mL}$ to be used as the single cytotoxicity test solution. Cisplatin test solution was diluted using culture medium to the concentration of $1,2,5,10,15$, 30 , and $50 \mu \mathrm{M}$. The combination treatment between extracts was made in several concentrations, which are $1 / 12,1 / 6$, and $1 / 3$ of the $\mathrm{IC}_{50}$ value.

\section{Cell preparation}

T47D cell suspension was grown in the TCD and was incubated in the $\mathrm{CO}_{2}$ incubator with a temperature of $37^{\circ} \mathrm{C}$. The cell condition was then observed under the microscope and then was incubated in the $5 \%$ $\mathrm{CO}_{2}$ incubator. After the cell became confluent $( \pm 80 \%)$, cell harvesting was done by removing the culture, washing the cell using $3 \mathrm{~mL}$ PBS 2 times, and then adding $0.25 \%$ trypsin-EDTA so that the cell was able to be released from the TCD. After $30 \mathrm{~s}$, the $0.25 \%$ trypsin-EDTA was removed, and the cell was incubated for $1 \mathrm{~min}$ in the $\mathrm{CO}_{2}$ incubator. 2-3 mL of media was added and then re-suspended so that the cells detached one by one. The cell suspension was then transferred to a new, sterile conical tube. The number of cells was calculated using hemocytometer and cell counter, and then, the cell suspension was made with the needed concentration. The single and combination cytotoxicity test was used the cell density of $8 \times 10^{4}$ cells per well plates.

\section{Single and combination cytotoxicity test using MTT assay}

The stock solution HCoL and TCa ethanolic extracts applied to T47D cells. ELISA reader was used to read the absorbance of life T47D cells at the wavelength of $595 \mathrm{~nm}$. Single treatment absorbance data were converted into the viability percentage and used to calculate the $\mathrm{IC}_{50}$ value. After the $\mathrm{IC}_{50}$ value was known, cytotoxicity test was conducted to the combination of HCoL and TCa extracts with the chemotherapeutic agent cisplatin in various combination ratios. Cytotoxicity test of HCoL and TCa extracts with cisplatin was done with the concentration below $\mathrm{IC}_{50}$ as shown in Table 1.

\section{Apoptosis and cycle cell observation}

The cells were treated with HCoL and TCa extracts and the combination between the two and cisplatin with a chosen concentration series. For the combination treatment, $300 \mu \mathrm{L}$ of $\mathrm{HCoL}$ and TCa extracts was added with $300 \mu \mathrm{L}$ of cisplatin with a concentration series, while for the single treatment, $900 \mu \mathrm{L}$ of HCoL and TCa extracts and cisplatin was added into the well plates following a concentration series. For the control cells, $900 \mu \mathrm{L}$ of culture medium was added to the well plates. After treatments, all cells were incubated for $24 \mathrm{~h}$. The cell precipitate formed was placed in conical tubes with aluminum foil as its cover and was diluted with annexin V-FLOUS buffer kit by adding $2 \mu \mathrm{L}$ PI and $2 \mu \mathrm{L}$ Annexin V. The cell suspension was homogenized and incubated for $10 \mathrm{~min}$ at room temperature with the conicals covered by aluminum foil. The cells were transferred into flow cytometry tubes and analyzed.

\section{Statistical analysis}

$\mathrm{IC}_{50}$ calculated with probit analysis method. Data obtained absorbance was converted to a percentage of living cells. Synergistic cytotoxic determined by calculating the combination index (CI) (CI combinatorial methods or index) and drug reduction index using software CompuSyn (www.combosyn.com) and the resulting isobologram. Flow cytometry data show the percentage of cells contained in four quadrants, namely lower left, lower right, upper left, and upper right. The quadrants to analyze the distribution of cells percentage in G1, S and G2/M phase. The inhibition of the cell cycle can be determined by comparing the treatment effect of the test solution with control cells.

\section{RESULTS}

Identification of chemical compounds in extract test

The test result on TCa stem extract (Fig. 1) shows one brown spot after being sprayed with cerium sulfate reagent that shows hRf 5 indicates that TCa stem contains carbon. After Dragendorff reagent was sprayed onto the plates, a spot with hRf of 25 in reddish orange. The spot indicates positive alkaloids if the color was brownish orange after being sprayed with Dragendorff reagent. Dragendorff $\left(\mathrm{BI}_{3} \mathrm{KI}\right)$ is a reagent widely used in identifying alkaloids where the heavy metal in the Dragendorff will create a bond with a lone pair electron in the $\mathrm{N}$ atom of alkaloids [16].

Silica gel $60 \mathrm{~F}_{254}$ as the stationary phase and the mixture of chloroform:methanol $(9: 1, \mathrm{v} / \mathrm{v})$ as the mobile phase

The test result on HCoL extract (Fig. 2) after being sprayed with cerium sulfate reagent shows 2 brown spots with the hRf value of 16 and 25 shows carbon atom, while no spots being spotted after spraying with Dragendorff reagent indicates that HCoL extract does not contain alkaloids.

Table 1: Ratio of concentration used in the combination of HCoL and TCa extracts with cisplatin

\begin{tabular}{llll}
\hline HCoLa $\left(1 / 12 \mathrm{IC}_{50}\right) ; \mathrm{TCa}\left(1 / 12 \mathrm{IC}_{50}\right) ; \mathrm{C}\left(1 / 12 \mathrm{IC}_{50}\right)$ & $\mathrm{HCoL}\left(1 / 12 \mathrm{IC}_{50}\right)$ & $\mathrm{TCa}\left(1 / 12 \mathrm{IC}_{50}\right)$ & $\mathrm{C}\left(1 / 12 \mathrm{IC}_{50}\right)$ \\
$\mathrm{HCoL}\left(1 / 6 \mathrm{IC}_{50}\right) ; \mathrm{TCa}\left(1 / 6 \mathrm{IC}_{50}\right) ; \mathrm{C}\left(1 / 6 \mathrm{IC}_{50}\right)$ & $\mathrm{HCoL}\left(1 / 6 \mathrm{IC}_{50}\right) ;$ & $\mathrm{TCa}\left(1 / 6 \mathrm{IC}_{50}\right)$ & $\mathrm{C}\left(1 / 6 \mathrm{IC}_{50}\right)$ \\
$\mathrm{HCoL}\left(1 / 3 \mathrm{IC}_{50}\right) ; \mathrm{TCa}\left(1 / 3 \mathrm{IC}_{50}\right) ; \mathrm{C}\left(1 / 3 \mathrm{IC}_{50}\right)$ & $\mathrm{HCoL}\left(1 / 3 \mathrm{IC}_{50}\right)$ & $\mathrm{TCa}\left(1 / 3 \mathrm{IC}_{50}\right)$ & $\mathrm{C}\left(1 / 3 \mathrm{IC}_{50}\right)$ \\
$\mathrm{CC}$ & $\mathrm{CC}$ & $\mathrm{MC}$ & $\mathrm{MC}$ \\
\hline
\end{tabular}

HCoL: Hedyotis Corymbosa L extract, TCa: Tinospora Crispa extract, C: Cisplatin, CC: Control cell, MC: Medium control 


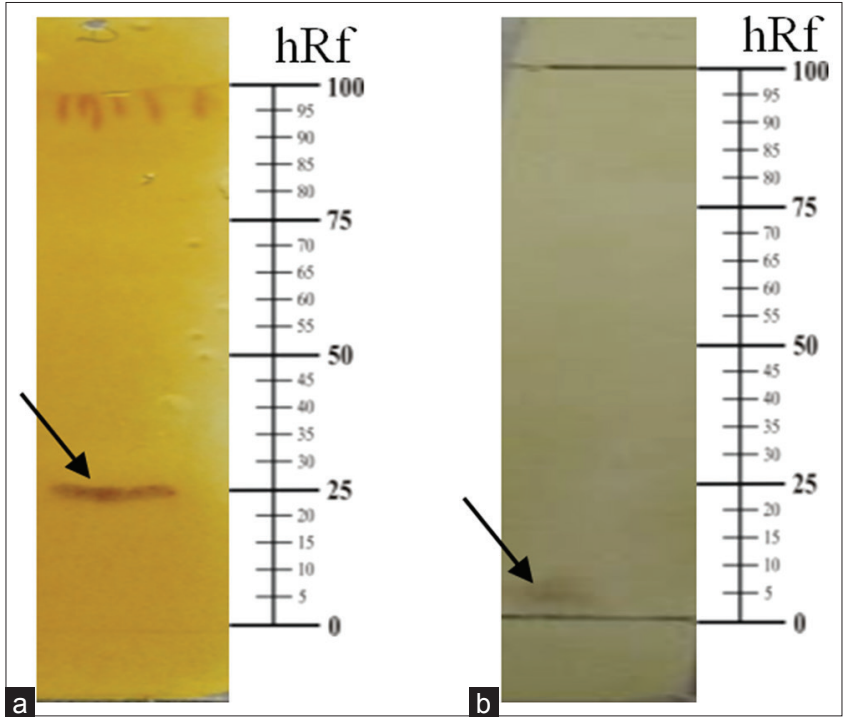

Fig. 1: Result of Dragendorff test result (a) cerium sulfate test (b) on Tinospora crispa

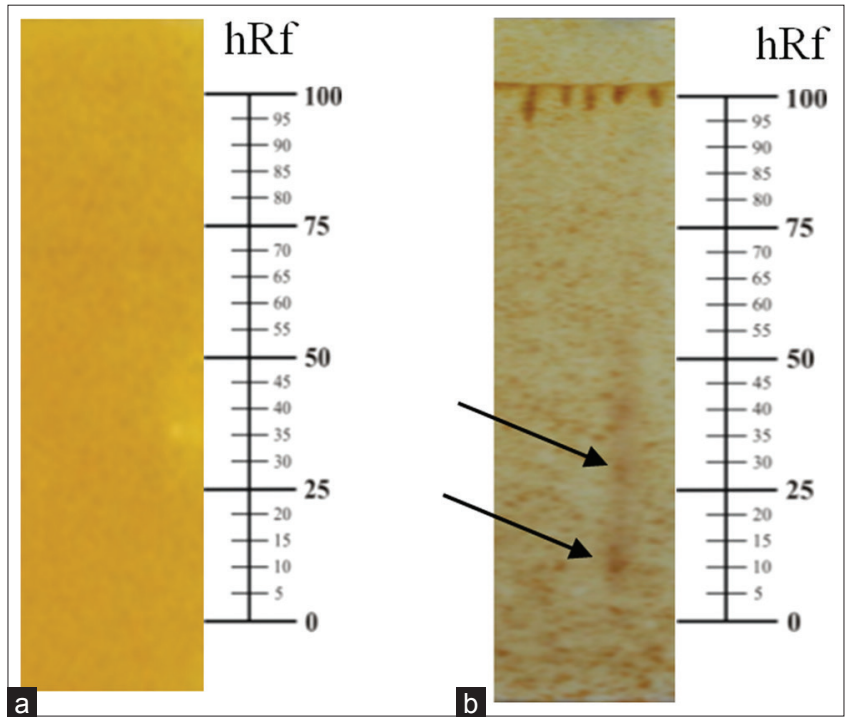

Fig. 2: Result of Dragendorff test (a) cerium sulfate test (b) on Hedyotis corymbosa L extract

Silica gel $60 \mathrm{~F}_{254}$ as the stationary phase and the mixture of chloroform: methanol $(9: 1, \mathrm{v} / \mathrm{v})$ as the mobile phase.

\section{Single cytotoxicity result on T47D cell lines}

Cytotoxicity test was done to determine the potential of ethanolic extracts of $\mathrm{HCoL}$ and TCa with cisplatin in inhibiting T47D breast cancer cell. Before the cytotoxicity test was done on the combination of the three, the individual IC $_{50}$ value was calculated to determine the concentration suitable for each component based on their $\mathrm{IC}_{50}$ value. In this research, treatment was done on T47D cells in DMEM high glucose medium with a $24 \mathrm{~h}$ incubation. The cytotoxic effect of ethanolic extract of HCoL, TCa, and cisplatin was shown with the decrease of cell viability and morphological change on T47D breast cancer cells (Table 2).

The treatment with the ethanolic extract of HCoL (Fig. 3b), TCa (Fig. 3c), and cisplatin (Fig. 3d) shows a decrease the number of living cells compared to the control (Fig. 3a). The cells look round and fragmented which indicates a change in cell morphology, but it is yet to know whether the cell death was caused by a necrosis or apoptosis process, with proliferation as its inhibition process.

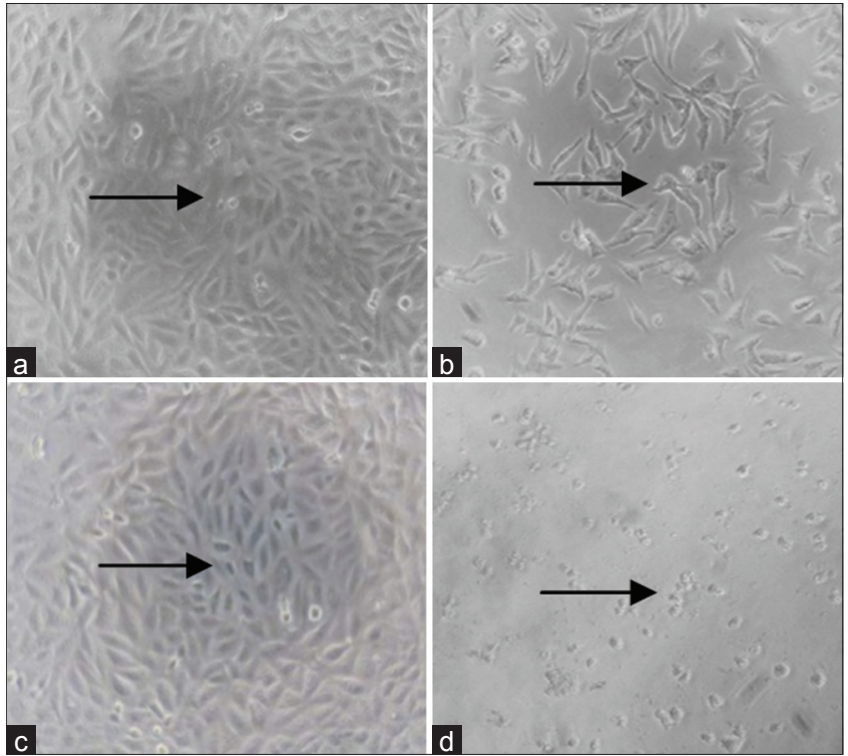

Fig. 3: Treatment effect on T47D cell lines. (a) Cell control; (b) $25 \mu \mathrm{g} / \mathrm{mL}$ ethanolic extract of Hedyotis corymbosa L; (c) 50 $\mu \mathrm{g} / \mathrm{mL}$ ethanolic extract of Tinospora crispa; and (d) $10 \mu \mathrm{g} / \mathrm{mL}$ cisplatin. The $\mathrm{IC}_{50}$ value was calculated from the linear regression between log of the concentration and percentage viability with the confidence value of $95 \%(p<0.05)$

Table 2: $\mathrm{IC}_{50}$ value of ethanolic extract of HCoL and TCa and cisplatin on T47D cells

\begin{tabular}{ll}
\hline Sample & IC $_{50}$ (mean \pm SD) \\
\hline Ethanolic extract of HCoL & $4.48 \pm 1.36 \mu \mathrm{g} / \mathrm{mL}$ \\
Ethanolic extract of TCa & $13.15 \pm 0.45 \mu \mathrm{g} / \mathrm{mL}$ \\
Cisplatin & $14.22 \pm 0.34 \mu \mathrm{M}$ \\
\hline
\end{tabular}

n: 5, SD: Standard deviation, $\mathrm{IC}_{50}$ : Inhibition concentration 50\%. HCoL: Hedyotis corymbosa L, TCa: Tinospora crispa

\section{Combination cytotoxicity test result on T47D breast cancer cell}

The cytotoxicity test on the combination was done to analyze the effect of adding the ethanolic extract of HCoL and TCa into the combination with cisplatin on T47D breast cancer cells. The concentration ratio used for the combination was $1 / 12,1 / 6$, and $1 / 3$ of the $\mathrm{IC}_{50}$ value. The concentrations were of a lower concentration compared to $\mathrm{IC}_{50^{\circ}}$. The combination is expected to be able to reduce the clinical side effects from the use of a chemotherapeutic agent, so it was done by reducing the concentration of cisplatin as the chemotherapeutic agent. The CI value was the parameter used to see the effect of the combination between the ethanolic extract of HCoL and TCa and cisplatin. The efficacy classifications produced were synergistic, additive, or antagonistic. The cytotoxicity test for the combination was done using MTT assay.

The concentration series of the combination for the ethanolic extract of HCoL was $0.5,1,2, \mu \mathrm{g} / \mathrm{mL}$ sequentially, the ethanolic extract of TCa was $2.5,5$, and $10 \mu \mathrm{g} / \mathrm{mL}$, and cisplatin was $1.25,2.5$, and $5 \mu \mathrm{M}$. The cell morphology changes of T47D cells caused by the combination of the ethanolic extract of $\mathrm{HCoL}$ and TCa with cisplatin show shrinkage and cell morphology changes (Fig. 4a-d). Combination ethanolic extract of HCoL and TCa with cisplatin at a concentration ratio of $1 / 12,1 / 6$, and $1 / 3$ resulted in the CI value not more than 1.00 (Table 3 ), so it proved that these combinations exhibited a synergistic effect.

The modulation of cell cycle from the combination on T47D breast cancer cells

The DNA synthesis on the cancer cells goes through a cell cycle, as the one on normal cells does. One of the main targets in inhibiting the proliferation of cancer cells is by the modulation of the cell cycle that 
can be observed through the flow cytometry method. Flow cytometry is able to detect each phase in the cell recycle based on the number of chromosomes in each phase (G1, S, and G2/M). The G1 phase has $2 n$ (diploid) chromosome, $S$ phase undergoes replication in the preparation of going into the G2 phase, so the number of chromosome sets is between $2 \mathrm{n}$ and $4 \mathrm{n}$, while G2 phase creates $4 \mathrm{n}$ (2 diploid cells) chromosome. PI was used to color each phase since it has the ability of interacting with DNA [17]. The observation of cell cycle profiles was done at the $24^{\text {th }} \mathrm{h}$. Flow cytometry analysis using the flowing program is shown in Fig. 5 and the detailed distribution percentage of the cell cycle is shown in Table 4.

The cell control undergoes a cell distribution in G1, S, and G2/M phase. Research shows that the ethanolic extract of HCoL results in the accumulation of cells in the $\mathrm{S}$ phase, while the ethanolic extract
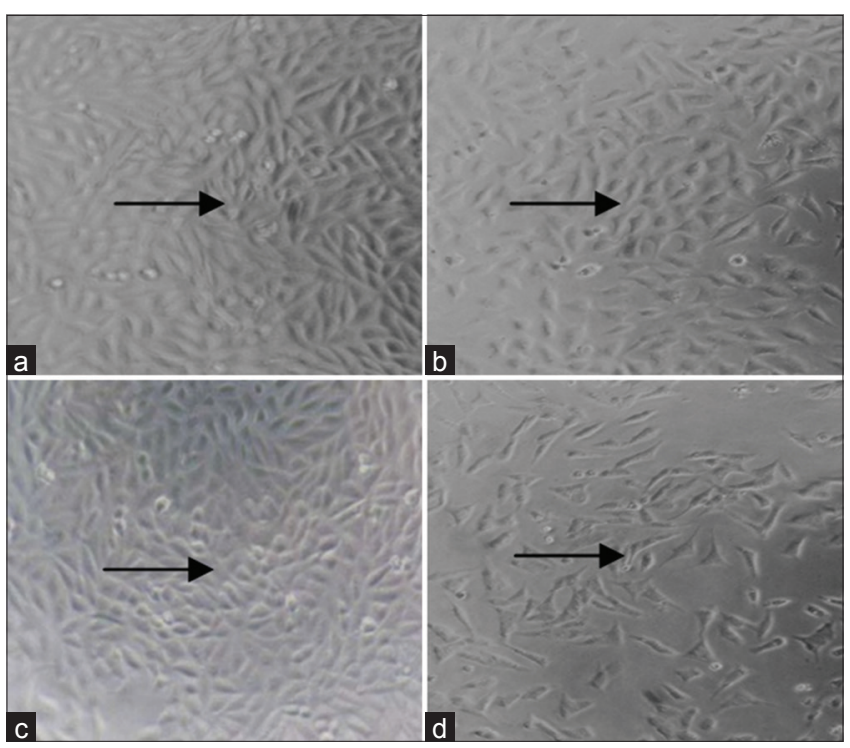

Fig. 4: The effect of treatment of the combination between the ethanolic extract of Hedyotis corymbosa L (HCoL) and Tinospora crispa (TCa) with cisplatin toward the growth of T47D cells. (a) Cell control; (b) combination ratio of $1 / 12$ IC $_{50}$; (c) combination ratio of $1 / 6 \mathrm{IC}_{50}$; and (d) combination ratio of $1 / 3 \mathrm{IC}_{50}$. The combination index (CI) value of the combination between the ethanolic extract of HCoL and TCa with cisplatin shows synergistic effect $(\mathrm{CI}<1)$.

Table 3: The CI value of the combination between cisplatin with the ethanolic extract of HCoL and TCa on T47D cells

\begin{tabular}{lll}
\hline Concentration ratio & Cell viability (\%) (mean \pm SD) & CI \\
\hline $1 / 12 \mathrm{IC}_{50}$ & $52.86 \pm 0.56$ & 0.43 \\
$1 / 6 \mathrm{IC}_{50}$ & $45.76 \pm 0.88$ & 0.58 \\
$1 / 3 \mathrm{IC}_{50}$ & $39.87 \pm 0.97$ & 0.86 \\
\hline
\end{tabular}

n: 5, SD: Standard deviation, CI: Combination Index. HCoL: Hedyotis corymbosa L, TCa: Tinospora crispa, SD: Standard deviation of TCa results in the accumulation of cells in the $\mathrm{S}$ and $\mathrm{G} 2 / \mathrm{M}$ phase. Cisplatin results in the accumulation of cells in the $S$ phase (Fig. 5). The combination of the three results in the accumulation of cells in the $\mathrm{S}$ phase compared to the cell control. With the combination treatment, the percentage of cell cycle distribution on the S phase was $29.48 \%$ higher than the treatment of only cisplatin with $11.24 \%$. The cell accumulation on the $\mathrm{S}$ phase in the combination treatment shows an increase compared to the cells without treatment (control cells) from $11.62 \%$ to $29.98 \%$. The cell accumulation was caused by cell cycle arrest in the said phase.

\section{Apoptosis effect from the combination}

Apoptosis induction was observed to know the cell mechanism caused by the treatment of the ethanolic extract of $\mathrm{TCa}$, the ethanolic extract of HCoL, cisplatin, and the combination of the three to T47D breast cancer cells after $24 \mathrm{~h}$ of incubation. Combination the ethanolic extract of HCoL, TCa, and cisplatin use $1 / 6 \mathrm{IC}_{50}$ concentration for apoptosis observation. . The method used in this research was the Annexin $\mathrm{V}$ method that was detected using flow cytometry to observe the apoptosis induction happened to the cells that was given treatment. Annexin V is a protein group that strongly binds negative charged cell membrane phospholipids. The cell death caused by apoptosis or necrosis can be differentiated by coloring using PI through intercalation with DNA18. The result of apoptosis induction test using flow cytometry (Fig. 6) and the percentage of cell death after the treatment of the combination between the ethanolic extract of HcoL and TCa with cisplatin which is caused by either apoptosis or necrosis is shown in Table 5.

The analysis of cell death percentage after the treatment of the ethanolic extract of HcoL, TCa, cisplatin, and the combination of the three (Table 5) shows that cells that were not given treatment exhibit living cells of $96.06 \%$ and cell death of $3.94 \%$. The cells that were given single treatment with the ethanolic extract HcoL show cell death of $3.61 \%$; treatment with the ethanolic extract of TCa shows cell death of $4.63 \%$; and treatment with cisplatin shows cell death of $6.04 \%$; while the treatment with a combination of the three shows cell death of $13.78 \%$. This shows that the cell death percentage at the treatment with the ethanolic extract of Hcol, TCa, and cisplatin shows an increase of $7.74 \%$ combined compared to only cisplatin so that the combination ratio of $1 / 6 \mathrm{IC}_{50}$ induces apoptosis.

The flow cytometry detection toward the cell death used Annexin $\mathrm{V}$ FLUOS on T47D breast cancer cells after the treatment of $1 \mu \mathrm{g} / \mathrm{mL}$ ethanolic extract of $\mathrm{HCoL}, 5 \mu \mathrm{g} / \mathrm{mL}$ ethanolic extract of $\mathrm{TCa}, 2.5 \mu \mathrm{M}$ cisplatin, and the combination of the three. R1 quadrant shows life cells, while R2 shows initial apoptosis, R3 shows final apoptosis, and R4 shows necrosis.

\section{DISCUSSION}

T47D cell is a type of breast cancer cells that have the characteristic of caspase-3 wild-type, caspase-7 wild-type, positive ER/PR, and p53 mutant [16]. The apoptosis induction that took place might has happened through the apoptosis mechanism that does not rely on p53. Cisplatin was reported to be able to induce downregulation Bcl-2 toward T47D breast cancer cells [17] and is able to create DNA crosslinks that result in damage in DNA that induces apoptosis [18]. Downregulation Bcl-2 (anti-apoptosis protein) will decrease the cell survivability and

Table 4: Percentage of cell cycle distribution after treatment

\begin{tabular}{lllc}
\hline Sample & G1 phase (\%) (mean \pm SD) & S phase (\%) (mean \pm SD) & G2/M phase (\%) (mean \pm SD) \\
\hline Control & $48.98 \pm 1.22$ & $11.62 \pm 1.45$ & $24.68 \pm 0.88$ \\
HCoL ethanolic extract $(1 \mu \mathrm{g} / \mathrm{mL})$ & $42.82 \pm 0.82$ & $17.92 \pm 0.99$ & $16.83 \pm 0.93$ \\
TCa ethanolic extract $(6 \mu \mathrm{g} / \mathrm{mL})$ & $34.83 \pm 0.60$ & $13.82 \pm 0.64$ & $24.83 \pm 0.43$ \\
Cisplatin $(2.5 \mu \mathrm{M})$ & $43.87 \pm 0.86$ & $11.24 \pm 0.87$ & $29.93 \pm 0.65$ \\
$1 \mu \mathrm{g} / \mathrm{mL}$ of ethanolic extract of $\mathrm{HCoL}+6 \mu \mathrm{g} / \mathrm{mL}$ & $24.82 \pm 0.65$ & $29.98 \pm 0.97$ & $15.98 \pm 0.39$ \\
of ethanolic extract of TCa+2.5 $\mu \mathrm{M}$ of cisplatin & & &
\end{tabular}

n: 5, SD: Standard deviation. HCoL: Hedyotis corymbosa L, TCa: Tinospora crispa 




Fig. 5. The effect of treatment of the combination between the ethanolic extract of Hedyotis corymbosa L (HCoL) and Tinospora crispa (TCa) with cisplatin toward the growth of T47D cells. (a) Cell control; (b) combination ratio of $1 / 12 \mathrm{IC}_{50}$; (c) combination ratio of $1 / 6 \mathrm{IC}_{50}$; (d) combination ratio of $1 / 3 \mathrm{IC}_{50}$; and (e) cisplatin. The combination index (CI) value of the combination between the ethanolic extract of HCoL and TCa with cisplatin shows synergistic effect $(\mathrm{CI}<1)$.

Table 5: Death percentage after treatment

\begin{tabular}{llllll}
\hline Process & $\begin{array}{l}\text { Without } \\
\text { treatment }\end{array}$ & $\begin{array}{l}\mathbf{1} \boldsymbol{\mu g} / \mathbf{m L} \\
\text { ethanolic } \\
\text { extract of HCoL }\end{array}$ & $\begin{array}{l}\mathbf{6} \boldsymbol{\mu g} / \mathbf{m L} \\
\text { ethanolic extract } \\
\text { of TCa }\end{array}$ & $\begin{array}{l}\mathbf{2 . 5} \boldsymbol{\mu M} \\
\text { cisplatin }\end{array}$ & $\begin{array}{l}\mathbf{1} \boldsymbol{\mu g} / \mathbf{m L} \text { ethanolic extract of } \\
\mathbf{H C o L}+\mathbf{6} \boldsymbol{\mu g} / \mathbf{m L} \text { ethanolic extract } \\
\text { of TCa+2.5 } \boldsymbol{\mu M} \text { cisplatin }\end{array}$ \\
\hline Initial apoptosis (\%) (mean \pm SD) & $1.45 \pm 0.13$ & $2.34 \pm 0.20$ & $1.52 \pm 0.11$ & $2.64 \pm 0.76$ & $10.92 \pm 1.23$ \\
Final apoptosis (\%) (mean \pm SD) & $1.63 \pm 0.12$ & $0.62 \pm 0.12$ & $2.13 \pm 0.54$ & $2.53 \pm 0.32$ & $1.24 \pm 0.98$ \\
Necrosis (\%) (mean $\pm S D)$ & $0.86 \pm 0.08$ & $0.65 \pm 0.54$ & $0.98 \pm 0.54$ & $0.87 \pm 0.43$ & $1.62 \pm 1.45$ \\
Total & $3.94 \pm 0.10$ & $3.61 \pm 0.23$ & $4.63 \pm 0.45$ & $6.04 \pm 0.98$ & $13.78 \pm 1.89$ \\
\hline
\end{tabular}

n: 5, SD: Standard deviation. HCoL: Hedyotis corymbosa L, TCa: Tinospora crispa

increases its sensitivity toward chemotherapeutic agent [19]. The result shows that the combination between the extracts and cisplatin increases apoptosis and undergoes cell cycle modulation at the $S$ phase. The modulation on $\mathrm{S}$ phase or $\mathrm{S}$ arrest renders cells unable to replicate and proliferate. The effects were also possible since the extracts contain several compounds, so the chance is high antagonistic effect to happen between the compounds, so it is needed to examine this further by analyzing the apoptosis induction of the compounds contained in the ethanolic extract of Hcol and Tca.

In the G1 and $\mathrm{S}$ phases, cell regulation was inhibited by cyclindependent kinase inhibitors such as INK4 and CIP/KIP proteins and tumor suppressor genes, namely pRB and p53. In this study used T47D cells that have mutations p53 so that the anticancer mechanism of the combination was possible through a p53 independent pathway [20]. Independent pathway of p53 status and the occurrence of arrest possibilities because of the rapid decline in Cdc25A activity due to ubiquitination and events its degradation by the proteasome [21]. Loss of activity of Cdc25A phosphatase inhibited the activity of CDK2 kinase by inhibiting CDK2 dephosphorylation in threonine 14 and tyrosine 15 [22]. Phosphorylation of Cdc25A is mediated by ATM/ATR-
Chk2/Chk1 cascade pathway. Degradation of Cdc25A phosphatasedependent on ATM-Chk2 where inhibiting CDK2 will initiate cdc45 (replication checkpoint) which reduces the speed of DNA replication so that DNA replication stops and triggers $S$ arrest [23]. The p38MAPK pathway also plays a role in the inhibition of cell cycle in phase $S$, which can occur through p53-independent [24]. The p38 protein can directly phosphorylate and stabilize $\mathrm{p} 21$ in vivo. The p38 protein may also phosphorylate and promote the degradation of Cdc25A which contributes to the termination of the cell cycle in phase $S$ [25].

Further research needed to discover which proteins are involved to understand the molecular mechanism that bridges the synergism between the compounds in the extracts, $\mathrm{p} 53$ protein expression, $\mathrm{Bcl}-2$, and NF-KB in vitro on the T47D breast cancer cells.

\section{CONCLUSION}

The combination between $1 / 6 \mathrm{IC}_{50}(1 \mu \mathrm{g} / \mathrm{mL})$ of the ethanolic extract of $\mathrm{HCoL}$ and $1 / 6 \mathrm{IC}_{50}(6 \mu \mathrm{g} / \mathrm{mL})$ of the ethanolic extract of TCa, and $2.5 \mu \mathrm{M}$ cisplatin is able to increase the cytotoxic effect of cisplatin toward T47D and has synergistic properties with the CI value of 0.58 . 




Fig. 6: The effect of apoptosis induction after the treatment of ethanolic extract of Hedyotis corymbosa $\mathrm{L}$, ethanolic extract of Tinospora crispa, cisplatin, and the combination

The combination between the ethanolic extract of HCoL and TCa with cisplatin inflicts $\mathrm{S}$ arrest on T47D breast cancer cells. The combination between the ethanolic extract of HCoL and TCa with cisplatin increases apoptosis induction on T47D breast cancer cells.

\section{ACKNOWLEDGMENTS}

Gratefully acknowledge for the financial support from Program of Chemistry, Faculty of Science and Technology, Ma Chung University. This study was supported by Microbiology laboratory, Faculty of Medicine, Brawijaya University.

\section{AUTHORS' CONTRIBUTIONS}

Rollando Rollando participated in developing the research protocol, fieldwork supervision, data analysis, and drafting this manuscript.

\section{CONFLICTS OF INTEREST}

The authors declare that there are no conflicts of interest regarding the publication of this paper.

\section{REFERENCES}

1. Bray F, Jemal A, Grey N, Ferlay J, Forman D. Global cancer transitions according to the Human Development Index (2008-2030): A population-based study. Lancet Oncol 2012;13:790-801.

2. Ferlay J, Soerjomataram I, Dikshit R, Eser S, Mathers C, Rebelo M, et al. Cancer incidence and mortality worldwide: Sources, methods and major patterns in GLOBOCAN 2012. Int J Cancer 2015;136:359-86.

3. Cardoso F, Harbeck N, Fallowfield L, Kyriakides S, Senkus E. Locally recurrent or metastatic breast cancer: ESMO clinical practice guidelines for diagnosis, treatment and follow-up. Ann Oncol 2012;23:11-9.

4. Valeriote F, Grieshaber CK, Media J, Pietraszkewicz H, Hoffmann J, Pan M, et al. Discovery and development of anticancer agents from plants. J Exp Ther Oncol 2002;2:228-36

5. Rebucci M, Michiels C. Molecular aspects of cancer cell resistance to chemotherapy. Biochem Pharmacol 2013;85:1219-26.

6. Minami M, Matsumoto S, Horiuchi H. Cardiovascular side-effects of modern cancer therapy. Circ J Off J Japanese Circ Soc 2010;74:1779-86.

7. Incorvati JA, Shah S, Mu Y, Lu J. Targeted therapy for early HER2 positive breast cancer. J Hematol Oncol 2013;6:1-9.

8. Jerusalem G, Rorive A, Collignon J. Use of mTOR inhibitors in the treatment of breast cancer: An evaluation of factors that influence patient outcomes. Breast Cancer Targets Ther 2014;6:43-57.

9. Noviyani R, Indrayathi PA, Budiana IN, Suwiyoga K, Tunas K. Assessment of life quality in patiens with stage IIB-IIIB squamous cell cervical cancer receiving paclitaxel cisplatin chemotherapy regiment by EORTC QLQ-C30 questionnaire in sanglah hospital denpasar. Int J Pharm Pharm Sci 2017;9:22-6.

10. Gautam RK, Singh RK, Ms K. Evaluation of nephroprotective activity of menthe arvensis in cisplatin induced nephrotoxicity. Asian J Pharm Clin Res 2014;7:188-91.

11. Florea AM, Büsselberg D. Cisplatin as an anti-tumor drug: Cellular mechanisms of activity, drug resistance and induced side effects. Cancers 2011;3:1351-71

12. Al-zubaidy AA, Sahib HB, Hussein ZA. The anti-angiogenic activity of Phoenix dactylifera seeds extracts. Int J Pharm Pharm Sci 2015;8:311-5.

13. Pitaloka DA, Sukandar EY. In vitro study of ursolic acid combination first-line antituberculosis drugs against drug-sensitive and drugresistant strains of Mycobacterium tuberculosis. Asian J Pharm Clin Res 2017;10:216-8.

14. Choudhary MI, Ismail M, Shaari K, Abbaskhan A, Sattar SA, Lajis NH, et al. Cis-clerodane-type furanoditerpenoids from Tinospora crispa. J Nat Prod 2010;73:541-7.

15. Zhao L, Wientjes MG, Au JL. Evaluation of combination chemotherapy: Integration of nonlinear regression, curve shift, isobologram, and combination index analyses. Clin Cancer Res 2004;10:7994-8004.

16. Schafer JM, Lee ES, O'Regan RM, Yao K, Jordan VC. Rapid 
development of tamoxifen-stimulated mutant p53 breast tumors (T47D) in athymic mice. Clin Cancer Res 2000;6:4373-80.

17. Mokhtari MJ, Akbarzadeh A, Hashemi M. cisplatin induces down regulation of BCL2 in T47D breast cancer cell line. Adv Stud Biol 2012;4:19-25.

18. Jamieson ER, Lippard SJ. Structure, recognition, and processing of cisplatin-DNA adducts. Chem Rev 1999;99:2467-98.

19. Falck J, Petrini JH, Williams BR, Lukas J, Bartek J. The DNA damage dependent intra-S phase checkpoint is regulated by parallel pathways. Nature Genet 2002;30:290-4.

20. Mailand N, Falck J, Lukas C, Syljuasen RG, Welcker M, Bartek J. Rapid destruction of Cde25A in response to DNA damage. Science 2002;88:1425-9.

21. Costanzo V, Robertson K, Ying CY, Kim E, Avvedoimento E, Gottesman M. Reconstitution of an ATM-dependent checkpoint that inhibits chromosomal DNA replication following DNA damage. Mol Cell 2000;6:649-59

22. Yuniati Y, Rollando R. Isolation of antibacterial compounds from endophyte fungal of Fusarium sp. In Phyllanthus niruri linn. Leaves. J Pharm Sci Res 2018;10:260-4.

23. Rollando R. Hedyotis corymbosa L. and Sterculia quadrifida R.Br ethanolic extract enhances cisplatin's cytotoxicity on T47D breast cancer cells through cell cycle modulation. J Pure Appl Chem Res 2018;7:63-75.

24. Kim GY, Mercer SE, Ewton DZ, Yan Z, Jin K, Friedman E. The stressactivated protein kinases p38 alpha and JNK1 Stabilize p21(Cip1) BY phosphorylation. J Biol Chem 2002;277:29792-802.

25. Goloudina A, Yamaguchi H, Chervyakova, DB, Appella E, Fornace AJ, Bulavin DV. Regulation of human Cdc25A stability by serine 75 phosphorylation is not sufficient to activate a s phase checkpoint. Cell Cycle 2003;2:269-73. 